\title{
Theoretical and Experimental Study of a New Imidazo (1,2-a) Pyridine Derivative as a Corrosion Inhibitor for the Carbon Steel Surface in the Saline Media
}

\author{
Rehab Majed Kubba ${ }^{1, *}$, Nada Mohammed Al-Joborry ${ }^{1}$ \\ ${ }^{1}$ Department of Chemistry, College of Science, University of Baghdad, Baghdad, Iraq.
}

\begin{tabular}{|c|c|}
\hline Articles Information & Abstract \\
\hline Received: & \multirow{11}{*}{$\begin{array}{l}\text { Newly synthesis derivative of imidazo }(1,2-a) \text { pyridine namely, } 2 \text {-(4-Bromo- } \\
\text { phenyl)-2,3-dihydro-imidazo[1,2-a] pyridine-3-yl methylene]- phenyl-amine } \\
\text { (BDIPMA) was investigated as corrosion inhibitor for carbon steel in saline } \\
\text { solution (3.5\% NaCl) using potentiometric polarization measurements. } \\
\text { Experimentally, the thermodynamic parameters obtained have supported a } \\
\text { physical adsorption mechanism and the adsorption followed the Langmuir } \\
\text { adsorption isotherm. Quantum mechanical method of the Density Functional } \\
\text { Theory (DFT) of B3LYP with [6-311++G }(2 \mathrm{~d}, 2 \mathrm{p})] \text { level were used to calculate the } \\
\text { optimized structure, chemical inhibition efficiency parameter (\%IE) and physical } \\
\text { properties in vacuum and two solvents (DMSO and H2O), all at the equilibrium } \\
\text { geometry. The surface changes of the carbon steel were studied using SEM and } \\
\text { AFM techniques. }\end{array}$} \\
\hline $24,10,2019$ & \\
\hline Accepted: & \\
\hline $29,12,2019$ & \\
\hline Published: & \\
\hline 01, March, 2020 & \\
\hline Keywords: & \\
\hline Imidazo[1,2-a]pyridine & \\
\hline Corrosion inhibitors & \\
\hline Quantum chemical calculations & \\
\hline Thermodynamic parameters & \\
\hline
\end{tabular}

DOI: 10.22401/ANJS.23.1.03

* Corresponding author: Rehab_mmr_kb@yahoo.com

\section{Introduction}

Corrosion of mineral has been an obstacle of the industry development due to the undesirable changes in the material properties caused by the corrosion process, like in dimensions, appearance of metal and losing chemical properties, then a huge economic losses was occur [1]. There are many methods to inhibit corrosion, one of these methods are using inhibitors. Inhibitor is a substance added in a small concentration to corrosive media causes decrease in corrosion rate of the area that exposed to that environment [2]. Many of inhibitors that used in industry are organic heterocyclic compounds mainly containing nitrogen, oxygen and sometimes sulfur atoms. In addition these inhibitors consisting of double or triple bonds that make adsorption mechanism of these substances on the surfaces are more easily [3]. Organic heterocyclic inhibitors usually have hetero atoms, higher basicity and electron density. The heteroatoms causes high susceptibility to resist corrosion, these inhibitors are favor for corrosion inhibition. The mechanism of these inhibitors is adsorption mechanism. These inhibitors forming a preventative film on the metal surface. Quantum calculations had been used to study the reaction mechanism and to solve chemical opacity. Lately, Density Functional Theory (DFT) has been used to resolve the characteristics of the interaction between inhibitor and metal surface, also to describe the nature of inhibitor structure on corrosion process [4-6]. The electronic and structural parameters of the inhibitor molecule can be gained by the theoretical calculations using computational methodologies of quantum chemistry [7]. The aim of this research is to study theoretically and experimentally the inhibition efficiency of newly organic inhibitor of Imidazo[1,2a]pyridine (BDIPMA); a heterocyclic entities and pharmacologically important molecule which was recently prepared by Sallom, K.J. [8]. (BDIPMA) was chosen theoretically from many prepared organic compound (which was prepared by Sallom) to be a good corrosion inhibitor depending on studying their quantum mechanical inhibition 


\section{Al-Nahrain Journal of Science}

ANJS, Vol.23 (1), March, 2020, pp. $13-26$

efficiency parameters computed using PM3 and G (2d, 2p) level of theory. Then its inhibition efficiency was proven practically on carbon-steel corrosion in $3.5 \% \mathrm{NaCl}$ solution using potentiodynamic polarization, Scanning Electron Microscopy (SEM) measurements and Atomic Force Microscopy (AFM) measurements.

\section{Experimental details}

\subsection{Preparation of carbon steel samples}

Carbon steel's rod was symbolized as C45 with the following percentage of metallic materials in composition (wt \%): $(0.122 \% \mathrm{C}, 0.206 \% \mathrm{Si}, 0.641 \%$ Mn, $0.016 \% \mathrm{P}, 0.031 \% \mathrm{~S}, 0.118 \% \mathrm{Cr}, 0.02 \% \mathrm{Mo}$, $0.105 \% \mathrm{Ni}$, and $0.451 \% \mathrm{Cu}$ ) [9]. The rod mechanically cutting into pieces forming a cyclic specimen of carbon steel a with $1.6 \mathrm{~cm}$ diameter and $3 \mathrm{~mm}$ thickness, each of these specimen was refined with emery paper (silicon carbide Sic) in different grades $(80,150,220,320,400,1000,1200$ and 2000) grades, then washed with tap water, distilled water and degreased with acetone, washed again with distilled water, and finally they kept in a desiccators after it is dried in room temperature.

\subsection{Preparation solution}

\subsubsection{Blank solution}

$(100 \mathrm{ml})$ of distilled water was used to dissolved (35 $\mathrm{gm})$ of sodium chloride $(\mathrm{NaCl})$; transferred the formative solution in to (1L) volumetric flask, containing $6 \mathrm{ml}$ of dimethyl sulfoxide (DMSO) solvent. The volume of the solution was completed to $(1 \mathrm{~L})$ by adding distal water.

2.2.2. Preparation the saline solutions (3.5\% $\mathrm{NaCl})$ of 2-(4-Bromo-phenyl)-2,3dihydro-imidazo[1,2-a]pyridine-3-yl methylene]-phenyl-amine (BDIPMA)

$(0.005,0.01$ and 0.02$) \mathrm{gm}$ of (BDIPMA) inhibitor were dissolved in $6 \mathrm{~mL}$ (DMSO) to prepare three concentration (5, 10 and 20) ppm respectively, then transferred each one into 1liter volumetric flask containing $35 \mathrm{~g}(3.5 \%)$ of $\mathrm{NaCl}$ dissolved in distal water. The volume of each solution was completed to $(1 \mathrm{~L})$ with the distal water.
DFT methods with (6-311 basis set) and (B3LYP ++

\subsection{Electrochemical measurements}

\subsubsection{Potentiostatic polarization study}

The potentiostat constitute has included the following: a host computer with Mat lab software (Germany, 2000), magnetic stirrer, thermostat, potentiostat and galvanostat. The main part in apparatus is the corrosion cell; it's made of pyrex with (1L) capacity. This cell consists of two bowls external and internal. Three electrodes are mainly present in the electrochemical corrosion cell, carbon steel specimen having $\left(1 \mathrm{~cm}^{2}\right)$ surface area represented as working electrode that is used to determine the working electrode potential due to another electrode namely reference electrode, put in a closed to working electrode. The reference electrode was $(\mathrm{Ag} / \mathrm{AgCl}, 3.0 \mathrm{M} \mathrm{KCl})$. The last electrode is a platinum auxiliary electrode with $(10 \mathrm{~cm})$ length. The starting step was represented in immersing the working electrode in test solution for fifteen minutes $(15 \mathrm{~min})$, to create a steady state [open circuit potential $\left(\mathrm{E}_{\mathrm{ocp}}\right)$ ]. This potential was noted for starting the electrochemical measurements in the range of $( \pm 200) \mathrm{mV}$. Each one of the solutions were tested at different temperatures (of 293, 303, 313 and 323) K.

\subsection{Results and discussion}

Molecular Structure: The two dimensional structures of the organic inhibitor (BDIPMA) was built by using the Chem Draw of Mopac program, (see figure 1 (a)). (Gaussian 09) packages [10] were used to calculate the fully optimize structure, see figure 1 (b), using DFT quantum mechanical method, Becke's three-parameter of Lee, Yang and Parr (B3LYP) with a 6-311++G (2d,2p) level of theory [11]. In addition to vacuum, the equilibrium geometry of (BDIPMA) was calculated in two solvents (DMSO and $\mathrm{H}_{2} \mathrm{O}$ ). 


\section{Al-Nahrain Journal of Science}

ANJS, Vol.23 (1), March, 2020, pp. $13-26$

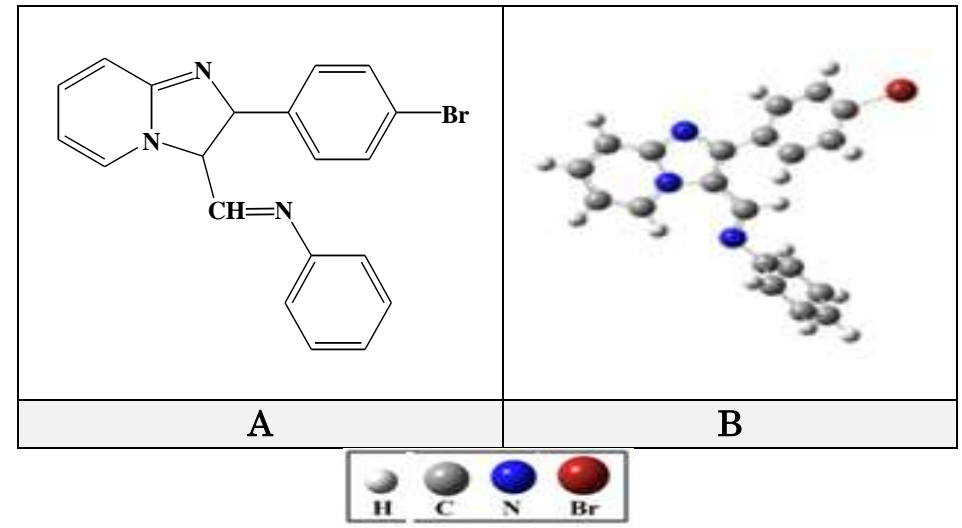

Figure 1. a; 2Dimensional structure of (BDIPMA), and b; 3Dimensional optimize structure of (BDIPMA) inhibitor.

Table 1 shows the geometrical structure of compound (BDIPMA), such as (bond lengths, bond angels and dihedral angles), in vacuum, DMSO, and $\mathrm{H}_{2} \mathrm{O}$. Figure 2, shows the numbering of the atoms for compound (BDIPMA). From Table (1), $\mathrm{C} 13-\mathrm{Br}(1.965 \AA)$ is the longest bond length and $\mathbf{C}_{11^{-}}$

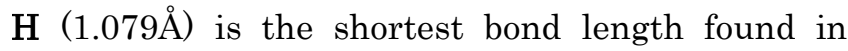
(BDIPMA) compound. The bond angles were calculated between $\left(104.700 \mathrm{~A}^{\circ}\right)$ for $\mathrm{N}_{4} \mathrm{C}_{7} \mathrm{C}_{8}$ and $\left(131.333 \mathrm{~A}^{\circ}\right)$ for $\mathbf{C}_{3} \mathbf{N}_{4} \mathbf{C}_{7}$. The values of the dihedral angles (trans \& cis) showed that the compound is not planar (with point group of $\mathrm{C}_{1}$ ) [the cis dihedral angles are not (zero) degree and all of the trans dihedral angles are more or less than (180.0 degree)].

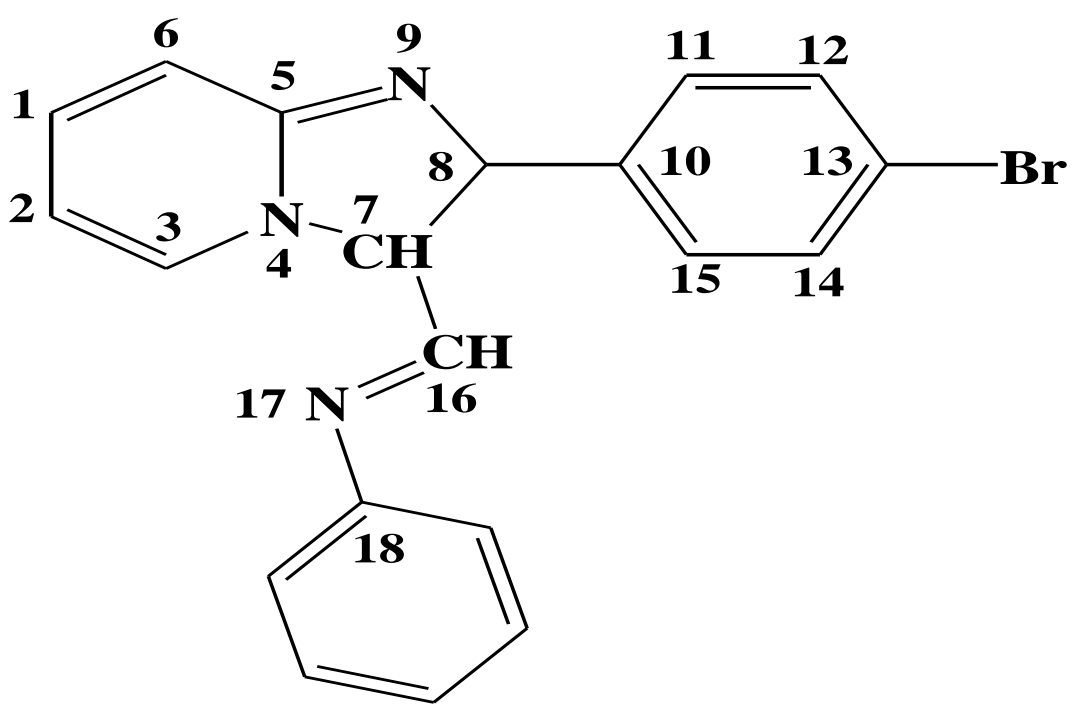

Figure 2. The numbering of atoms of compound (BDIPMA). 


\section{Al-Nahrain Journal of Science}

ANJS, Vol.23 (1), March, 2020, pp. $13-26$

Table 1. The geometrical structure of compound (BDIPMA) in vacuum and two solvents (DMSO, and $\mathrm{H}_{2} \mathrm{O}$ ) calculated using (DFT) method.

\begin{tabular}{|c|c|c|c|c|c|}
\hline $\begin{array}{l}\text { Description bond } \\
\text { length }\end{array}$ & $\begin{array}{c}\text { Bond length } \\
\text { (̊) }\end{array}$ & $\begin{array}{l}\text { Description } \\
\text { angle }\end{array}$ & $\begin{array}{l}\text { Angle } \\
\text { (deg) }\end{array}$ & $\begin{array}{c}\text { Description Dihedral } \\
\text { angle }\end{array}$ & $\begin{array}{c}\text { Dihedral angle } \\
\text { (deg) }\end{array}$ \\
\hline $\mathrm{C}_{1} \cdot \mathrm{C}_{2}$ & 1.41905 & $\mathrm{C}_{6} \mathrm{C}_{1} \mathrm{C}_{2}$ & 120.31016 & $\mathrm{HC}_{1} \mathrm{C}_{2} \mathrm{H}$ & 0.05946 \\
\hline $\mathrm{C}_{1}-\mathrm{C}_{6}$ & 1.37674 & $\mathrm{C}_{1} \mathrm{C}_{2} \mathrm{C}_{3}$ & 120.94726 & $\mathrm{HC}_{1} \mathrm{C}_{2} \mathrm{C}_{3}$ & -179.90686 \\
\hline $\mathrm{C}_{1}-\mathrm{H}$ & 1.08066 & $\mathrm{C}_{2} \mathrm{C}_{3} \mathrm{~N}_{4}$ & 118.69806 & $\mathrm{HC}_{2} \mathrm{C}_{3} \mathrm{H}$ & 0.24810 \\
\hline $\mathrm{C}_{2}-\mathrm{C}_{3}$ & 1.37014 & $\mathrm{C}_{3} \mathrm{~N}_{4} \mathrm{C}_{5}$ & 121.74820 & $\mathrm{HC}_{2} \mathrm{C}_{3} \mathrm{~N}_{4}$ & -179.92920 \\
\hline $\mathrm{C}_{3}-\mathrm{N}_{4}$ & 1.38010 & $\mathrm{C}_{3} \mathrm{~N}_{4} \mathrm{C}_{7}$ & 131.33339 & $\mathrm{HC}_{3} \mathrm{~N}_{4} \mathrm{C}_{7}$ & 0.03852 \\
\hline $\mathrm{N}_{4}-\mathrm{C}_{5}$ & 1.40951 & $\mathrm{~N}_{4} \mathrm{C}_{5} \mathrm{C}_{6}$ & 119.03995 & $\mathrm{C}_{3} \mathrm{~N}_{4} \mathrm{C}_{5} \mathrm{C}_{6}$ & 0.63888 \\
\hline $\mathrm{N}_{4}-\mathrm{C}_{7}$ & 1.40432 & $\mathrm{~N}_{4} \mathrm{C}_{5} \mathrm{~N}_{9}$ & 110.63067 & $\mathrm{C}_{3} \mathrm{~N}_{4} \mathrm{C}_{5} \mathrm{~N}_{9}$ & -179.54376 \\
\hline $\mathrm{C}_{5}-\mathrm{C}_{6}$ & 1.40544 & $\mathrm{C}_{5} \mathrm{C}_{6} \mathrm{C}_{1}$ & 119.25365 & $\mathrm{~N}_{4} \mathrm{C}_{5} \mathrm{C}_{6} \mathrm{C}_{1}$ & -0.36340 \\
\hline $\mathrm{C}_{5}-\mathrm{N}_{9}$ & 1.35092 & $\mathrm{~N}_{4} \mathrm{C}_{7} \mathrm{C}_{8}$ & 104.70017 & $\mathrm{~N}_{4} \mathrm{C}_{5} \mathrm{C}_{6} \mathrm{H}$ & 179.68076 \\
\hline $\mathrm{C}_{7}-\mathrm{C}_{8}$ & 1.40803 & $\mathrm{~N}_{4} \mathrm{C}_{7} \mathrm{C}_{16}$ & 120.36679 & $\mathrm{~N}_{4} \mathrm{C}_{7} \mathrm{C}_{8} \mathrm{~N}_{9}$ & -0.27198 \\
\hline $\mathrm{C}_{7}-\mathrm{C}_{16}$ & 1.44288 & $\mathrm{C}_{7} \mathrm{C}_{8} \mathrm{~N}_{9}$ & 111.64397 & $\mathrm{~N}_{4} \mathrm{C}_{7} \mathrm{C}_{8} \mathrm{C}_{10}$ & -179.43134 \\
\hline $\mathrm{C}_{8}-\mathrm{N}_{9}$ & 1.36649 & $\mathrm{C}_{7} \mathrm{C}_{8} \mathrm{C}_{10}$ & 127.66014 & $\mathrm{C}_{7} \mathrm{C}_{8} \mathrm{~N}_{9} \mathrm{C}_{5}$ & 0.23308 \\
\hline $\mathrm{C}_{8}-\mathrm{C}_{10}$ & 1.47369 & $\mathrm{C}_{8} \mathrm{~N}_{9} \mathrm{C}_{5}$ & 106.10869 & $\mathrm{C}_{10} \mathrm{C}_{8} \mathrm{~N}_{9} \mathrm{C}_{5}$ & 179.45919 \\
\hline $\mathrm{C}_{10}-\mathrm{C}_{15}$ & 1.40193 & $\mathrm{C}_{8} \mathrm{C}_{10} \mathrm{C}_{15}$ & 121.58325 & $\mathrm{HC}_{11} \mathrm{C}_{12} \mathrm{H}$ & -0.74028 \\
\hline $\mathrm{C}_{11}-\mathrm{C}_{12}$ & 1.39438 & $\mathrm{C}_{10} \mathrm{C}_{11} \mathrm{C}_{12}$ & 120.78679 & $\mathrm{HC}_{11} \mathrm{C}_{12} \mathrm{C}_{13}$ & 179.26155 \\
\hline $\mathrm{C}_{11}-\mathrm{H}$ & 1.07999 & $\mathrm{C}_{11} \mathrm{C}_{12} \mathrm{C}_{13}$ & 119.15063 & ${ }^{-} \mathrm{HC}_{12} \mathrm{C}_{13} \mathrm{Br}$ & -0.00646 \\
\hline $\mathrm{C}_{12}-\mathrm{C}_{13}$ & 1.38980 & $\mathrm{C}_{12} \mathrm{C}_{13} \mathrm{C}_{14}$ & 121.43393 & $\mathrm{HC}_{12} \mathrm{C}_{13} \mathrm{C}_{14}$ & 179.56138 \\
\hline $\mathrm{C}_{13}-\mathrm{C}_{14}$ & 1.38989 & $\mathrm{C}_{12} \mathrm{C}_{13} \mathrm{Br}$ & 119.37896 & $\mathrm{BrC}_{13} \mathrm{C}_{14} \mathrm{H}$ & 0.53970 \\
\hline $\mathrm{C}_{13}-\mathrm{Br}$ & 1.96568 & $\mathrm{C}_{13} \mathrm{C}_{14} \mathrm{C}_{15}$ & 118.96940 & $\mathrm{BrC}_{13} \mathrm{C}_{14} \mathrm{C}_{15}$ & 179.96135 \\
\hline $\mathrm{C}_{16}-\mathrm{N}_{17}$ & 1.294 & $\mathrm{C}_{7} \mathrm{C}_{16} \mathrm{~N}_{17}$ & 122.80680 & $\mathrm{HC}_{14} \mathrm{C}_{15} \mathrm{C}_{10}$ & 179.70330 \\
\hline $\mathrm{N}_{17}-\mathrm{C}_{18}$ & 1.427 & $\mathrm{C}_{16} \mathrm{~N}_{17} \mathrm{C}_{18}$ & 119.46164 & $\mathrm{C}_{7} \mathrm{C}_{16} \mathrm{~N}_{17} \mathrm{C}_{18}$ & -179.467 \\
\hline
\end{tabular}

Figure 3 shows the geometrical optimization for the calculated inhibitor in vacuum, including Frontier molecular orbital (HOMO and LUMO) density distributions [12]. The HOMO is mainly located on (2-(4-bromo-phenyl)-2,3-dihydro-imidazo[1,2-

a]pyridine-3-yl) moiety, this indicates that the preferred actives sites for an electrophilic attack are located within the region around the nitrogen atoms. Moreover, the electronic density of LUMO was distributed at the aromatic ring and around the ring of (methylene]-phenyl-amine) moiety (which is the most planar region in the calculated inhibitor).

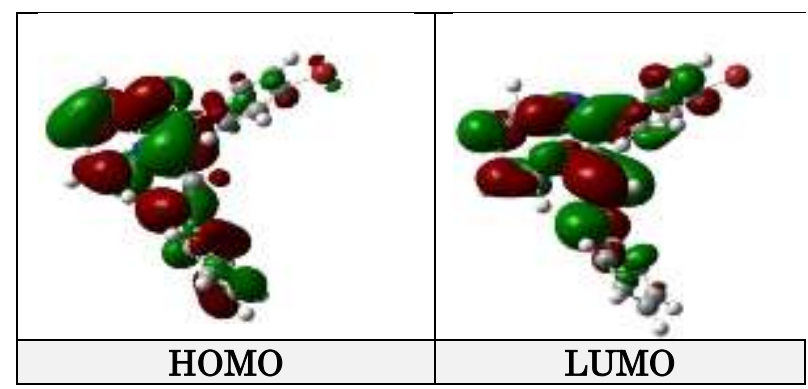

Figure 3. Frontier molecular orbitals of (BDIPMA) compound calculated using DFT method. [Red color: negatively charged lobe; blue color: positive charge lobe].

\section{Global molecular reactivity}

To study the influence of molecular structure on the mechanism and efficiency of inhibition, some chemical quantum parameters were calculated for studying the chemical parameters for corrosion efficiency, are shown in tables $(2,3)$. Frontier Orbital theory was used in the adsorption centers predicting the inhibitor that responsible of the reaction between the metal surface/ and organic molecule [13]. According to this theory, the formation of a transition state is due to an interaction between Frontier orbital's (HOMO and LUMO) of the reactants. The $\left(E_{\text {Номо }}\right)$ is often associated with the electron donating capacity of the molecule, thus, inhibitors that have high values of ( $\mathrm{E}_{\text {номо }}$ ) have a propensity to donate the electrons to suitable acceptor with the low empty molecular orbital energy. Conversely, $\left(E_{L U M O}\right)$ indicates the electron accepting capacity of the molecule. The lowest value of $\left(E_{L U M O}\right)$ indicates higher capability of accepting electrons. $\left(\triangle E_{\text {HOMO-LUMO }}\right)$; the energy gap between the Frontier orbital's, is another 


\section{Al-Nahrain Journal of Science}

ANJS, Vol.23 (1), March, 2020, pp. $13-26$

important factor in describing the molecular activity, so when ( $\left.\triangle E_{\text {HOMO-LUMO }}\right)$ decreased, the inhibition efficiency increased [14]. Activation hardness $(\eta)$; also defined on the basis of the $\left(\triangle E_{\text {Hомо-LUMO). The qualitative definition of }}\right.$ hardness $(\eta)$ is closely related to the polarizability, since any decrease in the $\left(\Delta E_{\text {gap }}\right)$ usually leads to easier polarization of the molecule. According to Koopman's theorem [15], the ionization potential $(I P)$ and electron affinity (EA) of the inhibitors could be calculated using the following Equations [16]:

$$
\begin{aligned}
& I P=-E_{\text {HOMO }} \\
& E A=-E_{L U M O}
\end{aligned}
$$

The electronegativity $(X)$ and the chemical hardness $(\eta)$ according to Pearson, estimated by the following relations $[17,18]$ :

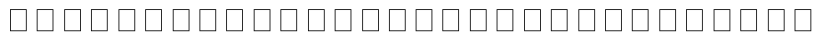

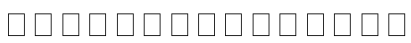$$
\eta=(I E-E A) / 2
$$

Global chemical softness (S), characterize the capacity of an atom or group of atoms to receive the electrons [10], calculated by Equation 5:

$$
S=1 / \square
$$

Parr introduced the Global electrophilicity index (w) [19], which was used for calculating the electronegativity $(X)$ and chemical hardness $(\eta)$ parameters, Equation 6.

$$
(\boldsymbol{\omega})=(-x)^{2 / 2 \eta}
$$

The fraction of electrons transferred $(\Delta N)$ from an inhibitor molecule to the surface of carbon steel was also calculated by using theoretical $\left(X_{F e}\right)$ and $\left(\eta_{F e}\right)$ values for mild steel of $\left(7.0 \mathrm{eV} \mathrm{mol}^{-1}\right)$ and $(0.0$ $\left.\mathrm{eV} \mathrm{mol}^{-1}\right)$, respectively. This parameter could be calculated using Equation 7 [19]:

$$
\Delta N=\left(X \mathrm{Fe}^{-}-X \text { inhib. }\right) /\left[2\left(\eta_{\mathrm{Fe}}+\eta_{\text {inhib. }}\right)\right]
$$

Tables $(2,3)$ show that (BDIPMA) compound was a good inhibitor depending on the values of quantum chemical parameters in three media (vacuum, DMSO and $\mathrm{H}_{2} \mathrm{O}$ ), as follows:

i. Dipol Moment $(\mu)$ in Debye is important electronic parameter that results from the non-uniform distribution of the charges on the various atoms in the molecule, high value of dipole moment causes increasing in the adsorption process between the chemical compound and the metal surface [18]. The $(\mu)$ for (BDIPMA) inhibitor was increased in both DMSO and $\mathrm{H}_{2} \mathrm{O}$ as a result of increasing the dipole moment of solution and increasing the dipole-dipole interactions between the solvent molecule and in the inhibitor. The aqueous solution can be regarded as a quasisubstitution process of the DMSO and water molecules by the inhibitor molecules at the metal surface (DMSOads and $\mathrm{H}_{2} \mathrm{Oads}$ ), Table (2).

ii. (IP); can be approximated as the negative of the (HOMO) energy [19]. Low values of (IP) increase the effectiveness of the inhibitor. The (IP) for (BDIPMA) inhibitor decreased in the DMSO and $\mathrm{H}_{2} \mathrm{O}$ solvents due to increasing in the value of ( Еномо $_{\text {. }}$.

iii. $E A$; is the amount of energy released when adding an electron to an atom or molecule [17]. A high value of (EA) indicates a good corrosion inhibitor. The electron affinity of (BDIPMA) was a higher on using DMSO and $\mathrm{H}_{2} \mathrm{O}$ solvents.

iv. ( $\eta)$; is a measure of the ability of atom or molecule to transfer the charge. Increasing (n) decreases the stability of molecule. Inhibitor possessed high value of $(\eta)$ considered to be a good inhibitor. (n) is increased in both DMSO and $\mathrm{H}_{2} \mathrm{O}$ solvents.

v. (S); is a measure of the flexibility of an atom to receive electrons. Molecules having high value of $\mathrm{S}$ considered to be good inhibitors. $(S)$ is decreased in solvents.

vi. $(\chi)$; is the ability of an atom or a group to pull electrons, high electronegativity indicates a good inhibitor. The calculated $(\chi)$ decreased in DMSO and $\mathrm{H}_{2} \mathrm{O}$ solvents, [20, 21].

vii. ( $\boldsymbol{\omega})$; is the measure of the stability of an atom after gaining an electron, low value of $(\omega)$ meaning good inhibition. ( $\boldsymbol{\omega})$ also decreased in both solvents DMSO and $\mathrm{H}_{2} \mathrm{O}$, [22].

viii. $\Delta N$; its value was increased in both solvents (DMSO and $\mathrm{H}_{2} \mathrm{O}$ ). 


\section{Al-Nahrain Journal of Science}

ANJS, Vol.23 (1), March, 2020, pp. $13-26$

Table 2. DFT results of the physical properties of BDIPMA inhibitor calculated at equilibrium geometry.

\begin{tabular}{lccccccc}
$\begin{array}{c}\text { Inhib. } \\
\text { Medium }\end{array}$ & P. G. & M. formula & Eномо $_{\text {HeV) }}$ & ELUmo $_{\text {LeV) }}$ & $\Delta \mathbf{E}_{\text {номо- LUmo }}(\mathrm{eV})$ & $\begin{array}{c}\mu \\
\text { (Debye) }\end{array}$ & $\mathbf{E}_{\text {total }}(\mathrm{eV})$ \\
\hline Vacuum & $\mathrm{C}_{1}$ & $\mathrm{C}_{20} \mathrm{H}_{16} \mathrm{~N}_{3} \mathrm{Br}$ & -6.228 & -1.938 & 4.290 & 3.085 & -95492.867 \\
DMSO & $\mathrm{C}_{1}$ & & -6.225 & -1.928 & 4.296 & 4.023 & -95493.142 \\
Water & $\mathrm{C}_{1}$ & & -6.225 & -1.929 & 4.296 & 4.035 & -95493.147 \\
\hline
\end{tabular}

Table 3. DFT quantum chemical parameters for BDIPMA inhibitor calculated at the equilibrium geometry.

\begin{tabular}{cccccccc}
\hline Inhib. medium & $\mathrm{IP}(\mathrm{eV})$ & $\mathrm{EA}(\mathrm{eV})$ & $\square(\mathrm{eV})$ & $\square(\mathrm{eV})$ & $\mathbf{S}(\mathrm{eV})$ & $\boldsymbol{\omega}(\mathrm{eV})$ & $\square \square$ \\
\hline Vacuum & 6.2288 & 1.9383 & 2.1452 & 4.0835 & 0.4661 & 3.8866 & 0.6797 \\
DMSO & 6.2250 & 1.9287 & 2.1481 & 4.0768 & 0.4655 & 3.8686 & 0.6804 \\
Water & 6.2255 & 1.9293 & 2.1481 & 4.0774 & 0.4655 & 3.8686 & 0.6804 \\
\hline
\end{tabular}

Active sites of the (BDIPMA) inhibitor

The inhibition of the studied inhibitors was done by using DFT Mulliken charges population analysis, which gave a signal of the reactive centers of the molecules (electrophilic and nucleophilic) centers. For that, region that have a large electronic charge are chemically softer than the region that have a small electronic charge. Thus, the density of electron may play an important role in the chemical reactivity calculation. The nucleophilic attack sites will be the place where the positive charge value is a maximum, and hence, only the charges on atoms such as (O), (N) and some (C) atoms would be present. The electrophilic attack site was controlled by the negative charge value. Table (4) shows Mulliken charges population analysis in (ecu unit) for (BDIPMA) in three media (vacuum, DMSO, and $\mathrm{H}_{2} \mathrm{O}$ ). According to this table, the orders of the nucleophihic reactive sites were found to be as: $\mathrm{C} 18>\mathrm{N} 9>\mathrm{C} 15>\mathrm{C} 12>\mathrm{C} 1>\mathrm{C} 14>\mathrm{C} 6>\mathrm{C} 3$, and the electrophihic reactive sites order were found to be as: $\mathrm{C} 10>\mathrm{C} 5>\mathrm{C} 13$.

Table 4. DFT Mulliken charges population analysis (ecu) for (BDIPMA) molecule in the three media (vacuum, DMSO, and $\mathrm{H}_{2} \mathrm{O}$ ).

\begin{tabular}{|c|c|c|c|c|c|}
\hline $\begin{array}{c}\text { Atom } \\
\text { no. }\end{array}$ & Electronic charge/ecu & $\begin{array}{c}\text { Atom } \\
\text { no. }\end{array}$ & Electronic charge/ ecu & $\begin{array}{c}\text { Atom } \\
\text { no. }\end{array}$ & Electronic charge/ ecu \\
\hline \multirow[t]{3}{*}{$\mathrm{C}_{1}$} & $0.309 \mathrm{~V}-$ & $\mathrm{C}_{7}$ & $0.140 \mathrm{~V}$ & $\mathrm{C}_{13}$ & $0.222 \mathrm{~V}$ \\
\hline & $-0.338 \mathrm{D}$ & & $0.130 \mathrm{D}$ & & $0.187 \mathrm{D}$ \\
\hline & $-0.339 \mathrm{H}$ & & $0.130 \mathrm{H}$ & & $0.186 \mathrm{H}$ \\
\hline \multirow[t]{3}{*}{$\mathrm{C}_{2}$} & $-0.006 \mathrm{~V}$ & $\mathrm{C}_{8}$ & $0.068 \mathrm{~V}$ & $\mathrm{C}_{14}$ & $-0.311 \mathrm{~V}$ \\
\hline & $-0.046 \mathrm{D}$ & & $0.125 \mathrm{D}$ & & $-0.319 \mathrm{D}$ \\
\hline & $-0.046 \mathrm{H}$ & & $0.126 \mathrm{H}$ & & $-0.319 \mathrm{H}$ \\
\hline \multirow[t]{3}{*}{$\mathrm{C}_{3}$} & $-0.290 \mathrm{~V}$ & $\mathrm{~N}_{9}$ & $-0.340 \mathrm{~V}$ & $\mathrm{C}_{15}$ & $-0.391 \mathrm{~V}$ \\
\hline & $-0.264 \mathrm{D}$ & & $-0.427 \mathrm{D}$ & & $-0.406 \mathrm{D}$ \\
\hline & $-0.263 \mathrm{H}$ & & $-0.429 \mathrm{H}$ & & $-0.406 \mathrm{H}$ \\
\hline \multirow[t]{3}{*}{$\mathrm{N}_{4}$} & $-0.017 \mathrm{~V}$ & $\mathrm{C}_{10}$ & $0.525 \mathrm{~V}$ & $\mathrm{C}_{16}$ & $0.143 \mathrm{~V}-$ \\
\hline & $-0.008 \mathrm{D}$ & & $0.474 \mathrm{D}$ & & $-0.105 \mathrm{D}$ \\
\hline & $-0.008 \mathrm{H}$ & & $0.474 \mathrm{H}$ & & $-0.105 \mathrm{H}$ \\
\hline \multirow[t]{3}{*}{$\mathrm{C}_{5}$} & $0.478 \mathrm{~V}$ & $\mathrm{C}_{11}$ & $-0.151 \mathrm{~V}$ & $\mathrm{~N}_{17}$ & $-0.047 \mathrm{~V}$ \\
\hline & $0.499 \mathrm{D}$ & & $-0.149 \mathrm{D}$ & & $-0.088 \mathrm{D}$ \\
\hline & $0.500 \mathrm{H}$ & & $-0.149 \mathrm{H}$ & & $-0.088 \mathrm{H}$ \\
\hline \multirow[t]{3}{*}{$\mathrm{C}_{6}$} & $-0.290 \mathrm{~V}$ & $\mathrm{C}_{12}$ & $-0.334 \mathrm{~V}$ & $\mathrm{C}_{18}$ & $-0.565 \mathrm{~V}$ \\
\hline & $-0.283 \mathrm{D}$ & & $-0.345 \mathrm{D}$ & & $-0.493 \mathrm{D}$ \\
\hline & $-0.283 \mathrm{H}$ & & $-0.346 \mathrm{H}$ & & $-0.492 \mathrm{H}$ \\
\hline \multirow[t]{3}{*}{$\mathbf{H}$} & $0.125 \mathrm{~V}$ & $\mathrm{H}$ & $0.165 \mathrm{~V}$ & $\mathrm{Br}$ & $0.087 \mathrm{~V}-$ \\
\hline & $0.146 \mathrm{D}$ & & $0.186 \mathrm{D}$ & & $0.095 \mathrm{D}-$ \\
\hline & $0.146 \mathrm{H}$ & & $0.186 \mathrm{H}$ & & $0.095 \mathrm{H}-$ \\
\hline
\end{tabular}

V: vacuum, D: dimethyl sulfoxide (DMSO), H: water, ecu: electron controstatic unit. 


\section{Al-Nahrain Journal of Science}

ANJS, Vol.23 (1), March, 2020, pp. $13-26$

\section{Potentiodynamic Polarization Measurements}

There are three polarization parameters can be used for characterizing the electrochemical kinetics of the metallic corrosion process such as; corrosion potential $\left(E_{\text {corr }}\right)$, corrosion current density $\left(I_{\text {corr. }}\right)$ and Tafel slopes ((ba) and/or $(b c))$. The corrosion behaviour can be determined by the polarization curve ( $\mathrm{E}$ versus $\log \mathrm{I}$ ). The valuation of the polarization parameters leads to determination the corrosion rate (C.R). By using Tafel extrapolation method, it's possible to obtain the $\left(I_{c o r r}\right)$ and the $\left(E_{c o r r}\right)$ by the extrapolation of cathodic and/or anodic Tafel lines [21]. The measurements were performed in $3.5 \% \mathrm{NaCl}$ solution containing different concentrations of the tested inhibitor (BDIPMA). The linear Tafel segments of anodic and cathodic curves were extrapolated to corrosion potential to obtain the corrosion current densities $\left(I_{\text {corr }}\right)$ and inhibition efficiency percentage (IE\%), Equation 8:

$$
\% I E=\frac{I_{\operatorname{corr}(\text { un })}-I_{\operatorname{corr}(\text { in })}}{I_{\operatorname{corr}(\text { un })}} \times 100
$$

Where $\left(I_{\text {corr }}(i n)\right)$, is the inhibited corrosion current densities, ( $\left.I_{\text {corr }}(u n)\right)$, is the uninhibited current densities. The values of polarization resistance $(R p)$ were calculated using Equation 9 [22]:

$$
R p=\frac{b_{a} \times b_{c}}{2.303\left(b_{a}+b_{c}\right) \times I_{c o r r}}
$$

The surface coverage $(\theta)$ of the carbon steel corrosion immersed in $3.5 \% \mathrm{NaCl}$ solution and acidic solution containing different concentrations (C) of (BDIPMA) could be estimated, using Equation 10:

\section{Corrosion inhibition measurement:

$$
\theta=\frac{\% I E}{100}
$$

While the corrosion rate $(C R)$ was calculated by Equation 11 [21]:

$$
C R=I_{\text {corr }} \times 0.249
$$

The addition of (BDIPMA) inhibitor cause a reduce in the corrosion rate, i.e. shifts of catholic and anodic curves to lower values of current densities, and both cathodes and anodic reactions of carbon steel electrode corrosion inhibited by the inhibitor in $3.5 \% \mathrm{NaCl}$ solution. Figure 4 shows potentiodynamic polarization curves for carbon steel (C45) in the salt solution, with and without the addition of (BDIPMA) inhibitor at various concentrations, and at the optimum conditions of (20ppm) with temperature of (293K). Table (5), shows the values of $(C R)$ of C.S and inhibition efficiency of inhibitor studied at various concentrations and different temperature in the saline solution. Tables 4 shows that the increase in temperature led to increase the corrosion current densities $I_{\text {corr. }}$, while the efficiencies (IE\%) enhance with the increase of the inhibitor concentration. The optimum conditions for (BDIPMA) in the salt solution were observed at $293 \mathrm{~K}$ and $20 \mathrm{ppm}$; which corresponded to the lowest $I_{\text {corr. }}\left(30.10 \mu \mathrm{A} . \mathrm{cm}^{-2}\right)$ and maximum $I E \%$ (of $77.39 \%$ ). The values of iron corrosion rate $\mathrm{CR}$ have decreased with increasing the concentration of the (BDIPMA) inhibitor and the addition of inhibitor to the blank solutions have led to increase the cathodic and anodic current densities without shifting the corrosion potential. So, the two inhibitors can be described as (mixedtype) inhibitors. Inhibition occurred by adsorption and the inhibition effect results from the reduction corrosion reaction on the carbon steel surface area [23]. 


\section{Al-Nahrain Journal of Science}

ANJS, Vol.23 (1), March, 2020, pp. $13-26$

Table 5. Electrochemical data of the carbon steel corrosion in $(3.5 \% \mathrm{NaCl})$ solution at the different concentrations of (BDIPMA) compound.

\begin{tabular}{|c|c|c|c|c|c|c|c|c|}
\hline Solu. & $\mathrm{T}(\mathrm{K})$ & $\mathbf{E}_{\text {corr }}(\mathrm{mV})$ & $I_{\text {corr }}\left(\mu \mathrm{A} . \mathrm{cm}^{-2}\right)$ & $\mathrm{Bc}\left(\mathrm{mV} \cdot \mathrm{dec}^{-1}\right)$ & $\mathrm{Ba}\left(\mathrm{mV} \cdot \mathrm{dec}^{-1}\right)$ & IE\% & $\boldsymbol{\theta}$ & CR mm. $\mathrm{y}^{-1}$ \\
\hline Blank & 293 & -408.0 & 133.13 & -230.4 & 138.5 & $\cdots-\cdot-\cdot$ & $-\cdots-\cdot$ & 33.15 \\
\hline \multirow[t]{3}{*}{$3.5 \% \mathrm{NaCl}$} & 303 & -446.7 & 172.04 & -279.6 & 110.2 & -.--. & $-\cdots-\cdot$ & 42.84 \\
\hline & 313 & -491.2 & 189.34 & -269.0 & 96.5 & $-\cdots-\cdot$ & $\cdots--\cdot$ & 47.15 \\
\hline & 323 & -547.7 & 192.99 & -252.9 & 84.4 & $\cdots-\cdot$ & $\cdots-\cdot-$ & 48.05 \\
\hline \multirow[t]{4}{*}{$5 \mathrm{ppm}$} & 293 & -385.3 & 35.29 & -96.5 & 98.9 & 73.49 & 0.735 & 7.85 \\
\hline & 303 & -382.5 & 46.06 & -223.5 & 191.6 & 73.22 & 0.732 & 10.38 \\
\hline & 313 & -344.7 & 51.58 & -246.4 & 192.6 & 72.75 & 0.728 & 12.64 \\
\hline & 323 & -335.7 & 53.77 & -191.2 & 161.9 & 72.13 & 0.721 & 13.89 \\
\hline \multirow[t]{4}{*}{$10 \mathrm{ppm}$} & 293 & -491.4 & 33.34 & -55.4 & 41.7 & 74.95 & 0.750 & 6.90 \\
\hline & 303 & -531.8 & 47.26 & -64.7 & 51.5 & 72.52 & 0.725 & 9.08 \\
\hline & 313 & -539.3 & 55.34 & -63.7 & 46.1 & 70.77 & 0.708 & 10.50 \\
\hline & 323 & -573.9 & 64.34 & -63.7 & 42.8 & 66.66 & 0.667 & 11.67 \\
\hline \multirow{4}{*}{$20 \mathrm{ppm}$} & 293 & -405.6 & 30.10 & -64.6 & 57.0 & 77.39 & 0.774 & 6.31 \\
\hline & 303 & -493.2 & 41.08 & -57.4 & 41.8 & 76.12 & 0.761 & 8.49 \\
\hline & 313 & -515.6 & 62.74 & -76.8 & 42.1 & 66.86 & 0.669 & 9.96 \\
\hline & 323 & 546.4 & 78.72 & -72.3 & 46.3 & 59.21 & 0.592 & 11.13 \\
\hline
\end{tabular}

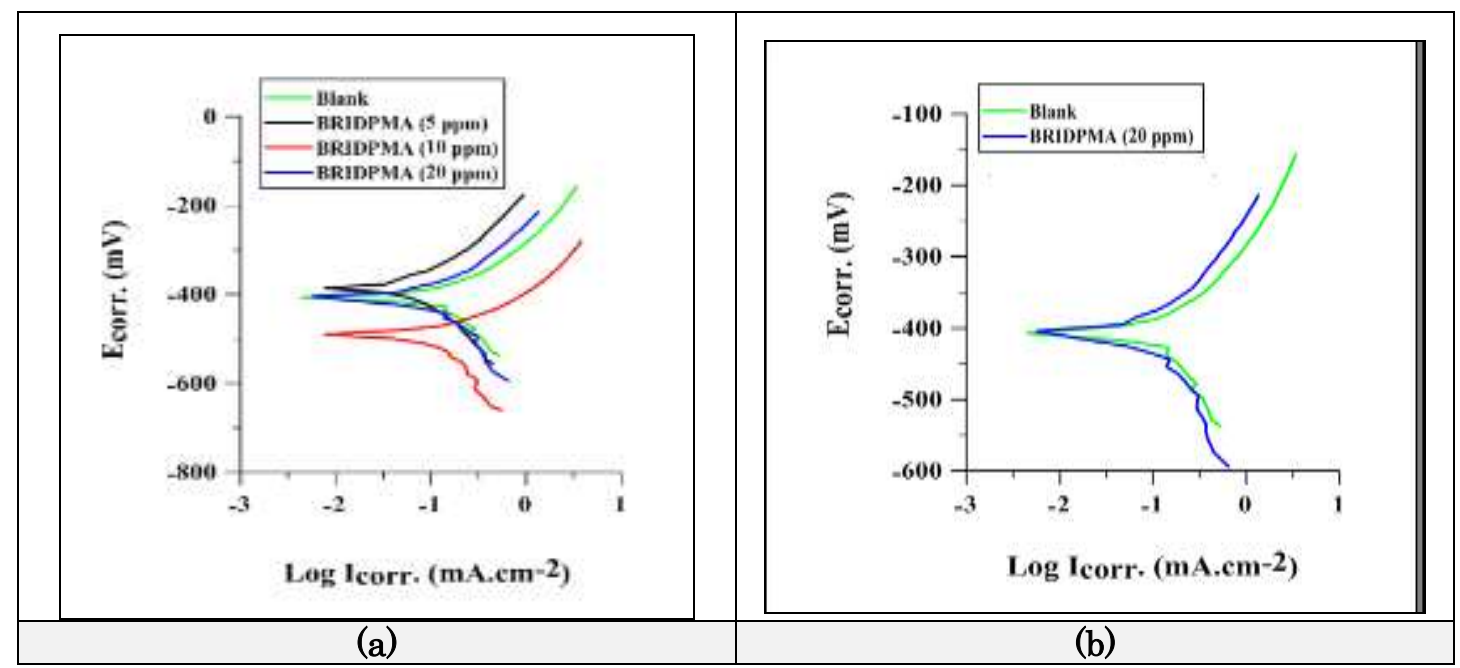

Figure 4. Polarisation curve of C.S in saline solution for (BDIPMA) compound, (a) at different concentrations and $\mathrm{T}$ (of 293K), (b) at the optimum concentration and $\mathrm{T}$ (of $293 \mathrm{~K}$ ).

Corrosion kinetic and thermodynamic activation parameters

Arrhenius equation (Equation 12) was used to study the effect of temperature on the inhibited corrosion reaction carbon steel [24].

$$
\log \left(I_{\text {corr }}\right)=\log A-E a / 2.303 R T \text { (12) }
$$

Where $E a$ is the energy activation of the corrosion reaction $\left(\mathrm{kJ} \mathrm{mol}^{-1}\right)$ and $\mathrm{A}$ is the pre-exponential factor (in molecules $\mathrm{cm}^{-2} \mathrm{~s}^{-1}$ ), $R$ is the gas constant and $\mathrm{T}$ is the absolute temperature (Kelvin). Values of (Ea) were derived from the slopes of linear relationship between (log icorr) versus (1/T), see figure $5(A)$ is obtained from the intercepts. The entropy of activation $\left(\Delta S^{*}\right)$ is related to the preexponential factor (A), Equation 13 [25]:

$$
A=K T / h \exp \left(\Delta S^{*} / R\right)
$$

Where $K$; is Boltzmann constant, $T$, is the absolute temperature in (Kelvin), and $\mathrm{h}$; is Planck's constant. Table (6) shows the values of the activation energy $(E a)$, pre-exponential factor $(A)$, and entropy of activation $\left(\Delta S^{*}\right)$ of C.S in the absence and in the presence of various 


\section{Al-Nahrain Journal of Science}

ANJS, Vol.23 (1), March, 2020, pp. $13-26$

concentrations of (BDIPMA). All ( $\left.E_{a}\right)$ values were higher than the value of the blank $(9.635 \mathrm{~kJ} / \mathrm{mol})$ pointing that the corrosion reaction of C.S is retarded by (BDIPMA). It also supports the physical adsorption [26]. A plot of the $[\log (C R / T)$ against (1/ T)] (Equation 14), give a linear relationship with a slope of $\left(-\Delta H^{*} / 2.303 R\right)$ and the intercept of $\left[\log (R / N h)+\left(\Delta S^{*} / 2.303 R\right)\right]$, see figure 6 for which the activation thermodynamic parameters $\left(\Delta S^{*}\right.$ and $\left.\Delta H^{*}\right)$ were calculated, Table (6).

$$
\begin{aligned}
\log (C R / T)= & \log (R / N h)+\Delta S^{*} / 2.303 R-\Delta H^{*} \\
& 2.303 R T \quad(14)
\end{aligned}
$$

Where $I_{\text {corr }}$; is the corrosion current density, $R$, is the universal gas constant ( $8.314 \mathrm{~J} \mathrm{~mol}^{-1} \cdot \mathrm{K}^{-1}$ ), $T$; is the absolute temperature in $\mathrm{K}, h$; is the Planck's constant $\left(6.626 \times 10^{-34} \mathrm{~J} \mathrm{~s}\right), N$, is the Avogadro's number $\left(6.022 \times 10^{23} \mathrm{~mol}^{-1}\right), \Delta H^{*}$, is the enthalpy of activation and $\Delta S^{*}$, is the entropy of activation. The enthalpy changes values $\left(\Delta H^{*}\right)$ of the corrosion reaction in $(3.5 \% \mathrm{NaCl})$ at the temperature range of (293-323) $\mathrm{K}$ and different concentration and the positive values that supporting the endothermic nature for this reaction [27]. Negative values of $\left(\Delta S^{*}\right)$ of corrosion reaction indicate a decrease in the degree of freedom and a consequent inhibition action. Values of $\left(\Delta G^{*}\right)$ for the corrosion process were calculated by the following relation:

$$
\Delta G^{*}=\Delta H^{*}-T \Delta S^{*} \ldots \text { (15) }
$$

\begin{tabular}{|c|c|c|c|c|c|c|c|c|c|}
\hline $\begin{array}{l}\text { Conc. } \\
\text { (ppm) }\end{array}$ & $293 K$ & $\begin{array}{c}\Delta \mathrm{G} \\
303 K\end{array}$ & $\begin{array}{l}\mathrm{J} / \mathrm{mol} \\
\quad 313 \mathrm{~K}\end{array}$ & $323 K$ & $\Delta \mathrm{H}^{*} \mathrm{~kJ} / \mathrm{mol}$ & $\Delta \mathrm{S}^{*} \mathrm{~kJ} / \mathrm{mol} \mathrm{K}$ & $\mathrm{Ea} \mathrm{kJ/} \mathrm{mol}$ & A & Molecule/ $\mathrm{cm}^{2} \mathrm{~S}$ \\
\hline Blank & 63.056 & 64.967 & 66.877 & 68.788 & 7.079 & -0.191 & 9.635 & & $1.10305 \mathrm{E}+27$ \\
\hline 5 & 66.292 & 68.268 & 70.045 & 71.221 & 8.385 & -0.198 & 10.941 & & $4.97275 \mathrm{E}+27$ \\
\hline 10 & 66.443 & 68.423 & 70.203 & 71.782 & 14.297 & -0.178 & 16.853 & & $5.30391 \mathrm{E}+27$ \\
\hline 20 & 66.826 & 68.605 & 70.784 & 71.963 & 23.494 & -0.148 & 26.040 & & $1.97513 \mathrm{E}+29$ \\
\hline
\end{tabular}

Table 6. Corrosion kinetic parameters for carbon steel in sea water ( $3.5 \% \mathrm{NaCl})$ for blank and with various concentrations of (BDIPMA) inhibitor.

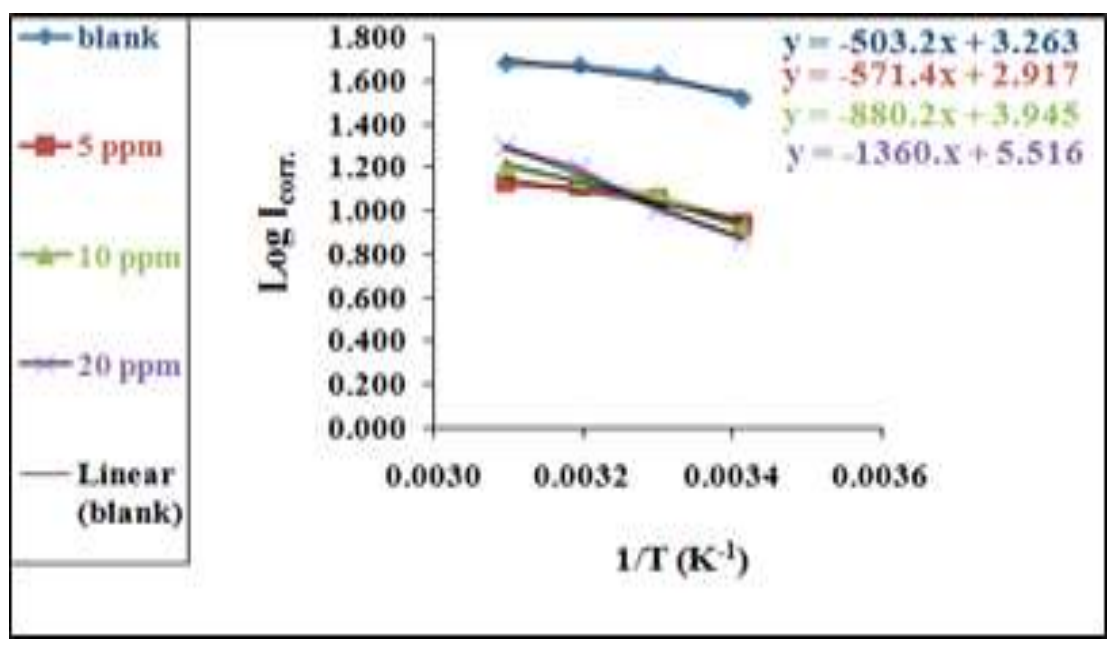

Figure 5. Plot for log (Icorr) vs (1/ T) for carbon steel in sea water for blank and in presence different concentrations of (BDIPMA) inhibitor. 


\section{Al-Nahrain Journal of Science}

ANJS, Vol.23 (1), March, 2020, pp. $13-26$

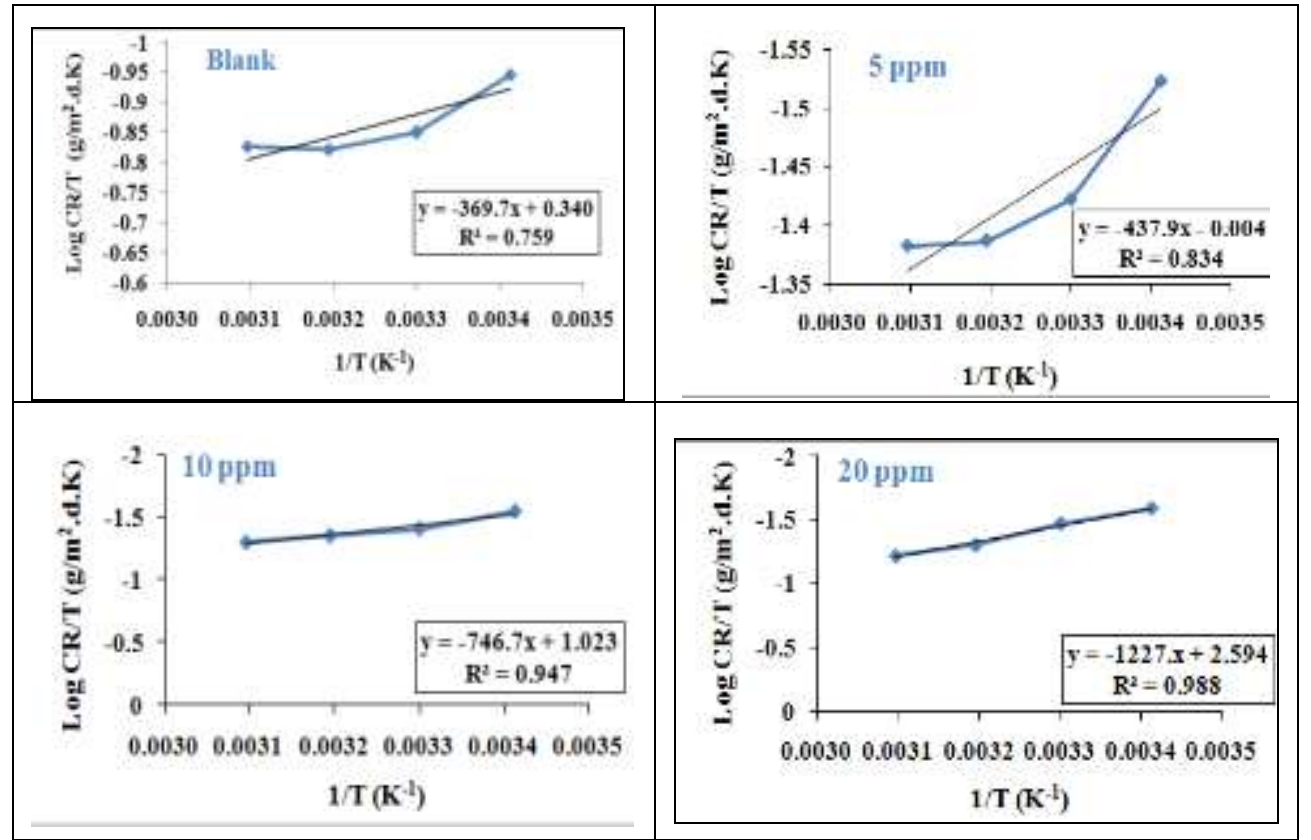

Figure 6. Plot of $\log (\mathrm{CR} / \mathrm{T})$ vs $(1 / \mathrm{T})$ for carbon steel in sea water for the blank solution and in presence of different concentrations of (BDIPMA) inhibitor.

\section{Adsorption isotherm}

Adsorption isotherm is useful to characterize the reaction between the surface of the C.S and inhibitor molecule. It is affected by the nature of the charge of the metal, the chemical structure of inhibitor, type of the electrolyte $\mathrm{pH}$ and temperature [27]. Langmuir adsorption isotherm is one of the most frequently used isotherms, can be described by Equation 15:

$$
C / \theta=\left(1 / K_{a d s}\right)+C(15)
$$

Where $(C)$; is inhibitor concentration, $\left(K_{a d s}\right)$; is adsorption equilibrium constant and $(\theta)$; is the surface coverage. The dependence of the fraction $(\mathrm{C} /$ $\theta)$ as a function of ( $C$ ) for (BDIPMA) is shown in Figure 8 . The obtained plots of the inhibitor were almost linear. The equilibrium constant of adsorption $\left(K_{a d s}\right)$ is related to the standard free energy of adsorption ( $\Delta G_{a d s}$ ) according to the following equation:

$$
\Delta G_{a d s}=-2.303 R T \log \left(55.55 K_{a d s}\right) \quad \text { (16) }
$$

Whereas $R$, is the gas constant ( $\left.\mathrm{J} \mathrm{K}^{-1} \mathrm{~mol}^{-1}\right), T$, is the absolute temperature $\mathrm{K}$, and 55.5 is the concentration of water in solution expressed in (M). Table (7) shows the thermodynamic functions of the adsorption process. By plotting [ $K_{a d s}$ versus (1/T)] the $\left(\Delta G_{\text {ads }}^{\circ}\right)$ was extracted from the slope. Entropy and enthalpy adsorption values were obtained by using the Equations $(17,18)[28]$ :

$$
\begin{gathered}
\Delta G^{\circ}{ }_{a d s}=-R T \ln K a d s \quad \text { (17) } \\
\Delta G^{\circ}{ }_{a d s}=\Delta H^{\circ} \text { ads }-T \Delta S^{\circ} \text { ads (18) }
\end{gathered}
$$

Negative values of the $\left(\Delta G_{a d s}^{\circ}\right)$ indicating the spontaneous adsorption. Generally, the values of $\left(\Delta G^{\circ}{ }_{a d s}\right)$ around $\left(-20 \mathrm{~kJ} \mathrm{~mol}^{-1}\right)$ or less negative are consistent with electrostatic interaction (physisorption), while those $\left(-40 \mathrm{~kJ} \mathrm{~mol}^{-1}\right)$ and more negative involve electron transfer to form chemical bond (chemisorptions) [28]. So the values of ( $\left.\Delta G^{\circ}{ }_{a d s}\right)$ that obtained in this work were found in the range of $\left(-11.440\right.$ to $\left.-7.724 \mathrm{~kJ} \mathrm{~mol}^{-1}\right)$ at the different temperatures (293-323K) indicates that the adsorption for (BDIPMA) is physisorption. The higher value of the equilibrium constant $\left(\mathrm{K}_{\mathrm{abs}}=\right.$ $6.890 \times 10^{5}$ ) which obtained from the Langmuir isotherm for (BDIPMA) indicates stronger adsorption on the C.S surface in $3.5 \% \mathrm{NaCl}$ aqueous solution. For a (physisorption) process $\left(\Delta \mathrm{H}^{\circ}{ }_{\text {ads }}\right)$ is lower than $\left(40 \mathrm{~kJ} \mathrm{~mol}^{-1}\right)$ while the adsorption heat of a chemisorption process approaches $(100 \mathrm{~kJ}$ $\mathrm{mol}^{-1}$ ). In this study; the average value of adsorption heat is (-39.289 $\left.\mathrm{kJ} \mathrm{mol} \mathrm{m}^{-1}\right)$ supporting physisorption process of (BDIPMA) on C.S surface [24]. The entropy $\Delta S^{\circ}$ ads value was positive, these 


\section{Al-Nahrain Journal of Science}

ANJS, Vol.23 (1), March, 2020, pp. $13-26$

values of the entropy suggest that the quantity of inhibitor increases the order of the reactants to go to the formation the activated complex or as the inhibitor quantity increased the formed of the coated film becomes well ordered [19]. The negative value of $\left(\Delta H^{\circ}\right.$ ads $)$ (of $\left.-39.289 \mathrm{~kJ} \mathrm{~mol}{ }^{-1}\right)$ in the salt media indicates the adsorption of the inhibitory

Table 7. The thermodynamic parameters for adsorption of (BDIPMA) compound on the surface of C.S in $(3.5 \% \mathrm{NaCl})$ at various temperatures.

\begin{tabular}{|c|c|c|c|c|c|}
\hline $\begin{array}{c}\mathrm{T} \\
(\mathrm{K})\end{array}$ & $\begin{array}{c}\mathrm{K}_{\mathrm{ads}} \\
(\mathrm{L} \\
\left.\mathrm{mol}^{-1}\right)\end{array}$ & $\begin{array}{c}\Delta \mathrm{G}_{\mathrm{ads}}^{\circ} \\
(\mathrm{kJ} . \\
\left.\mathrm{mol}^{-1}\right)\end{array}$ & $\begin{array}{c}\Delta \mathrm{H}^{\circ} \text { ads } \\
\left(\mathrm{kJ} . \mathrm{mol}^{-}\right. \\
1)\end{array}$ & $\begin{array}{c}\Delta \mathbf{S}_{\text {ads }}^{\circ} \\
(\mathrm{kJ} . \mathrm{mol} \\
1)\end{array}$ & $\overline{\mathrm{R}^{2}}$ \\
\hline 293 & $\begin{array}{l}6.890 \\
\times 10^{5}\end{array}$ & $\begin{array}{c}- \\
11.440\end{array}$ & -39.289 & 0.053 & 0.999 \\
\hline 303 & $\begin{array}{l}6.455 \\
\times 10^{5}\end{array}$ & $\begin{array}{c}- \\
11.279\end{array}$ & & & 0.999 \\
\hline 313 & $\begin{array}{l}3.719 \\
\times 10^{5}\end{array}$ & $\begin{array}{c}- \\
09.913\end{array}$ & & & 0.999 \\
\hline 323 & $\begin{array}{r}1.537 \\
\times 10^{5} \\
\end{array}$ & $\begin{array}{c}- \\
07.724 \\
\end{array}$ & & & 0.998 \\
\hline
\end{tabular}

molecules on the surface of C.S is an exothermic process.

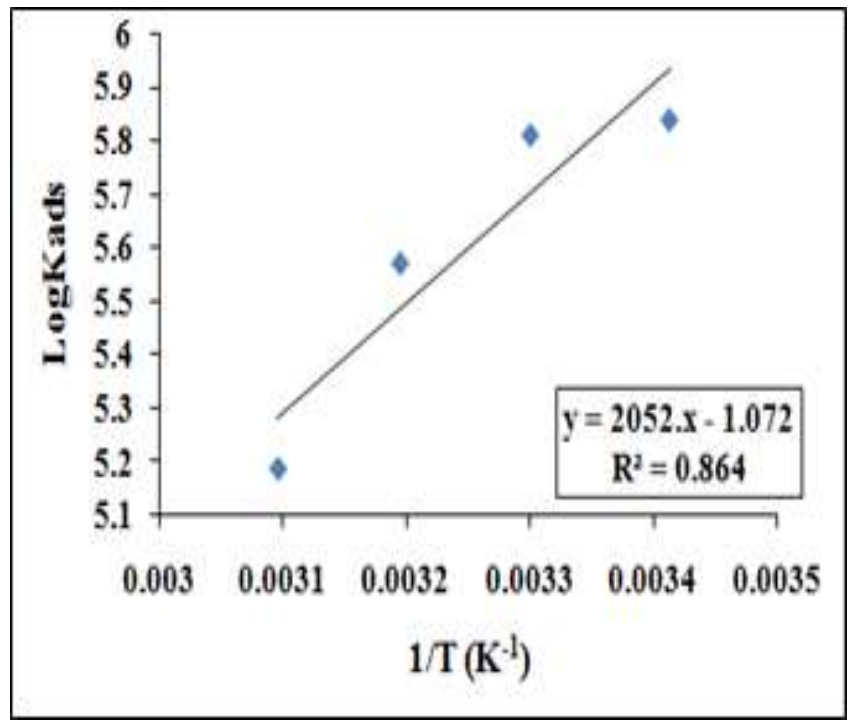

Figure 7. Plot of ( $\log \mathrm{Kads})$ vs (1/ T) for (BDIPMA) compound in the salty media.

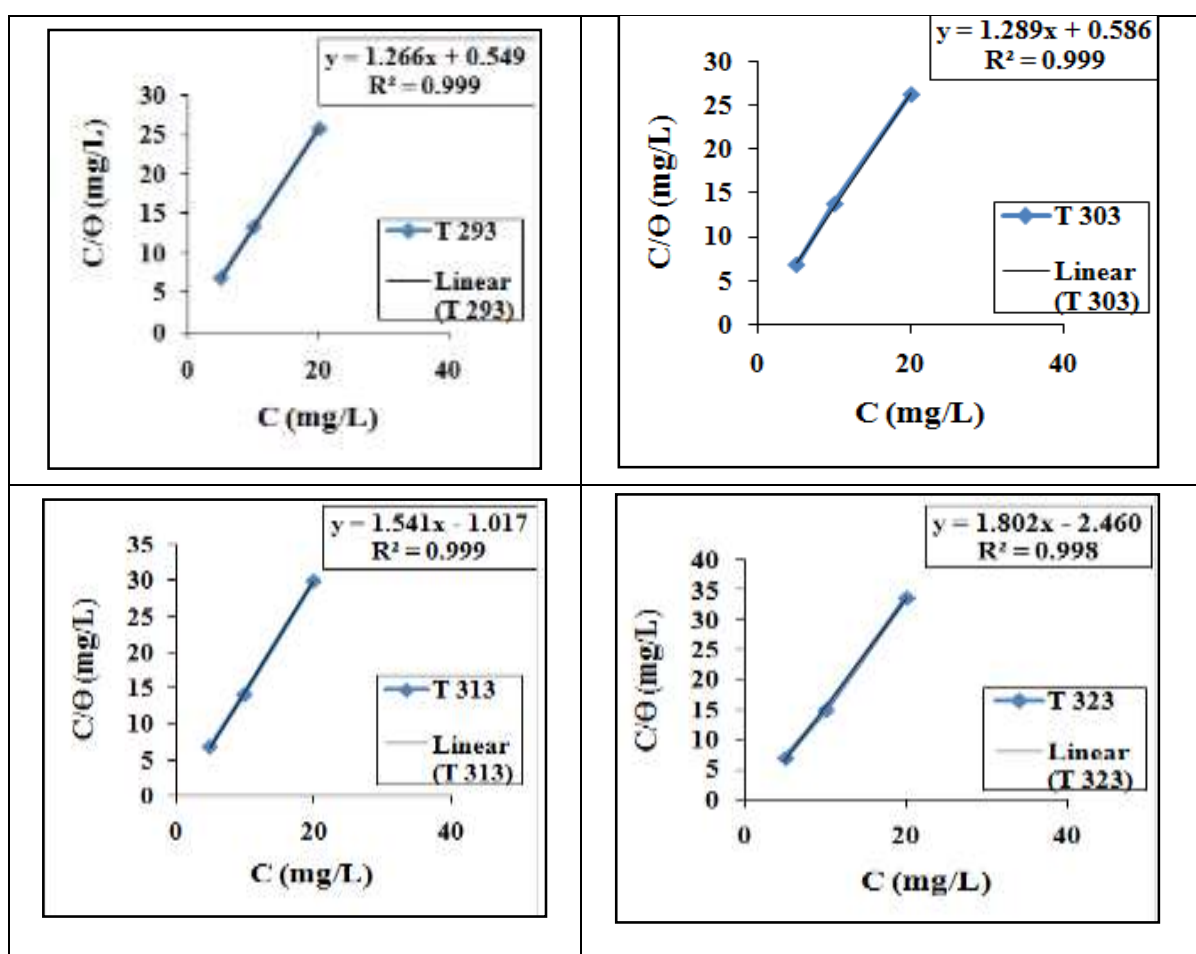

Figure 8. Langmuir isotherm plot for the adsorption of (BDIPMA) compound on C.S surface in salt media at the temperatures of $(293,303,313$ and 323$) \mathrm{K}$. 


\section{Al-Nahrain Journal of Science}

ANJS, Vol.23 (1), March, 2020, pp. $13-26$

Scanning Electron Microscopy (SEM) Measurement

Figure 9 (a) shows the destroying of the surface of carbon steel that obtained when the metal was remained immersed in saline water without (BDIPMA) inhibitor. However, figure 9 (b) shows the smoothness and regularity on the surface of carbon steel in the presence of (BDIPMA) inhibitor, in saline water when compared to figures 9 (a) which indicated the reduction of the surface corrosion. This improvement in the surface morphology is due to the formation of protective films of inhibitors (BDIPMA) on the carbon steel surface, and hence, indicated the inhibition of the corrosion [28].

\section{Atomic Force Microscopy (AFM)}

The surface morphology of the carbon steel samples in the salty solution of $(3.5 \% \mathrm{NaCl})$ absence and presence of the optimum concentration (20 ppm) of the inhibitor was scrupulous by (AFM). Figures $(10(a-d))$ shown the results. The average roughness that shown in figures $10(\mathrm{a}-\mathrm{b})$, described that the surfaces of C.S samples were badly damaged due to $(3.5 \% \mathrm{NaCl})$ salt attack. The average roughness $\left(\mathrm{S}_{\mathrm{a}}\right)$ for the surface carbon steel surface was $(3.97 \mathrm{~nm})$ in the salty solution without the presence of the (BDIPMA) inhibitor. $\left(\mathrm{S}_{\mathrm{a}}\right)$ was reduced to $(3.45 \mathrm{~nm})$ in presence of the optimum concentration (20 ppm) of the (BDIPMA) inhibitor that display the carbon steel surface after immersion in salt media [29], see figures $10(\mathrm{c}, \mathrm{d})$.

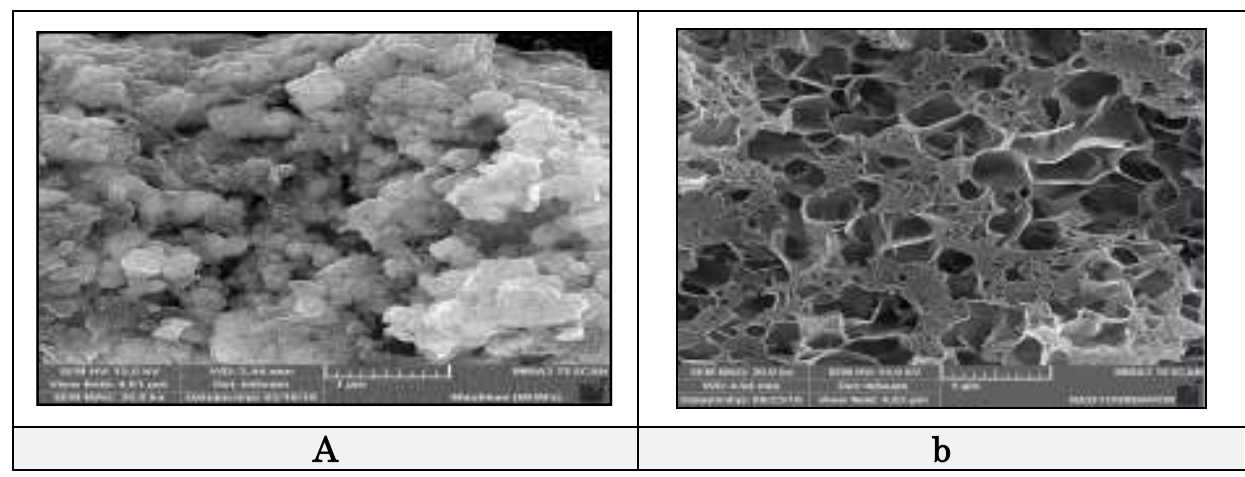

Figure 9. The (SEM) images of the surface of carbon steel surface a (3.5\% NaCl) solution at (293) $\mathrm{K}$ (a), without .(BDIPMA) inhibitor, and (b), in presence of 20 ppm (BDIPMA) inhibitor
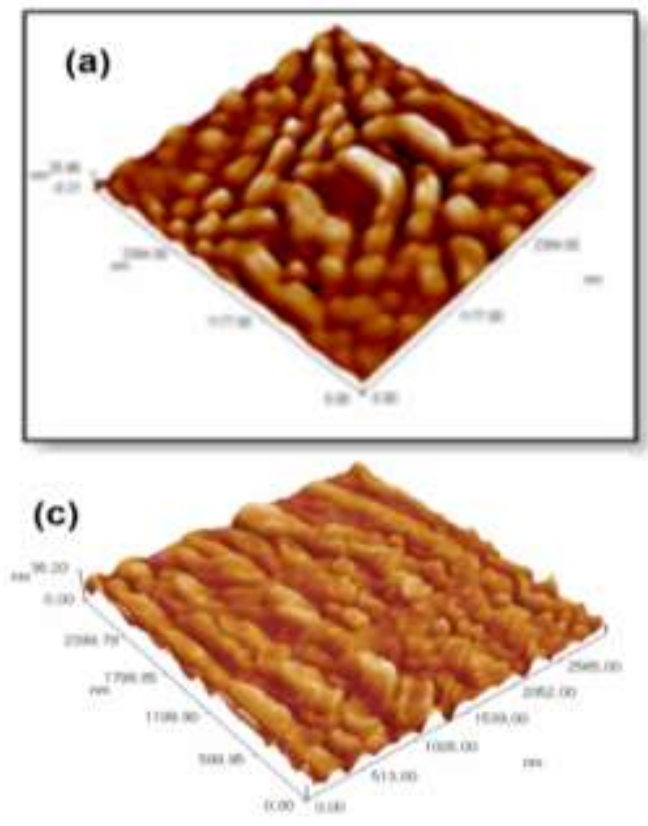

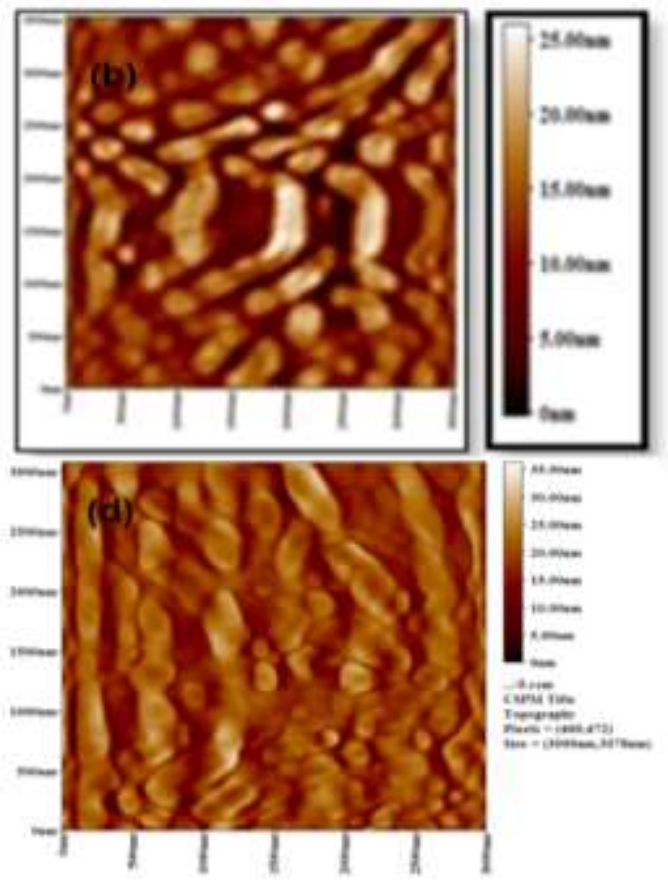

Figure 10. The (AFM) images of the carbon steel surface, $(a, b)$ in $(3.5 \% \mathrm{NaCl})$ solution, and $(c, d)$ in the presence of $(20 \mathrm{ppm})$ of the inhibitor. 


\section{Al-Nahrain Journal of Science \\ ANJS, Vol.23 (1), March, 2020, pp. 1-7}

\section{Conclusions}

The new synthesized (BDIPMA) derivative was theoretically proposed to be a good organic corrosion inhibitor for carbon steel surface. Results obtained from potentiodynamic polarization technique show that (BDIPMA) derivative acted as an effective corrosion inhibitor for C.S in $\mathrm{NaCl}$ aqueous solution with (IE\%) obtained (77.39\%) at 20 ppm (BDIPMA). Polarization result shows that (BDIPMA) acted as a mixed type corrosion inhibitor; adsorption on the C.S surface obeys Langmuir's adsorption isotherm. The negative values of $\Delta \mathrm{G}^{\circ}$ ads show the spontaneity of the adsorption and suggested that the inhibition process may occur by the (physical adsorption) process. The inhibition efficiency increased with increasing the inhibitor concentration and decrease with increase temperature (physisorption inhibition). Theoretical study showed that (BDIPMA) had multiple sites of adsorption. SEM and AFM images show a smoother surface for inhibited carbon steel samples than uninhibited one.

\section{Acknowledgements}

This study was supported by the College of Science, Department of Chemistry, University of Baghdad (UOB), Baghdad, Iraq.

\section{References}

[1] Kubba, R. M.; Challoob, D. A.; Hussen, S. M.; "Quantum Mechanical And Electrochemical Study of New Isatin Derivative as Corrosion Inhibitor for Carbon Steel in 3.5 \% NaCl”; Int. J. Sci. Res. 6 (7), 1656-1669, 2017.

[2] David, A.; "Predicting the Performance of Organic Corrosion Inhibitors"; Metals 7(553), 1-8, 2017.

[3] Aouniti, A.; Elmsellema, H.; Tighadouini, S.; Elazzouzi, M.; Radi, S.; Chetouani, A.; Hammouti, B.; Zarrouk, A.; "Schiff's Base Derived from 2Acetyl Thiophene as Corrosion Inhibitor of Steel in Acidic Medium” J. Taibah Univ. Sci. 10, 774-785, 2016.

[4] Khaled, K. F.; "Studies of Iron Corrosion Inhibition Using Chemical, Electrochemical and Computer Simulation Techniques"; Electrochimica Acta 55, 6523-653, 2010.

[5] Gutiérreza, E.; Rodrígueza, J.; Borbollaa, J., Rodrígueza J.; Thangarasu, P.; "Development of a Predictive Model for Corrosion Inhibition of Carbon Steel by Imidazole and Benzimidazole Derivatives" Corrosion Science 108, 23-35, 2016.

[6] Shaban, S. M.; "N-(3-(Dimethyl Benzyl Ammonio) Propyl) Alkanamide Chloride Derivatives as
Corrosion Inhibitors for Mild Steel in $1 \mathrm{M} \mathrm{Hcl}$ Solution: Experimental and Theoretical Investigation"; Res. Advances 6, 39784-39800, 2016.

[7] Zhang, J.; Qiao, G.; Hu, S.; Yan, Y.; Ren, Z.; Yu, L.; Theoretical Evaluation of Corrosion Inhibition Performance of Imidazoline Compounds with Different Hydrophilic Groups"; Corrosion Science 53, 147-152, 2011.

[8] Sallom, K. J.; "Synthesis and Biological Activity Evaluation of New Imidazo and Bis Imidazo (1,2-A) Pyridine Derivatives"; M.Sc. Thesis, University of Baghdad, College of Science, Baghdad, Iraq; 2019.

[9] Duboscq, J.; Sabot, R.; Jeannin, M.; Refait, P.; "Localized Corrosion of Carbon Steel in Seawater: Processes Occurring in Cathodic Zones"; Mat. Corr. 70(6), 941-1140, 2019.

[10] Frisch, M. J.; Pople, J. A.; "Gaussian 09, Revision E. 01. Gaussian, Inc., Wallingford Ct.; 2009.

[11] Becke, A.; "Density-Functional ThermoChemistry: iii. The Role of Exact Exchange"; J. Chem. Phys. 98, 5648-5652, 1993.

[12] Fleming, I.; "Frontier Orbitals and Organic Chemical Reactions"; John Wiley and Sons, Newyork; 1976.

[13] Zhang, J.; Liu, J.; Yu, W.; Yan, Y.; You, L.; Liu, L.; "Molecular Modeling of the Inhibition Mechanism of 1-(2-Aminoethyl)-2-Alkyl-Imidazoline"; Corrosion Science 52(6), 2059-2065, 2010.

[14] Singh, A.; Ansari, K. R.; Lin, Y.; Quraishi, M. A.; Lgaz, H.; Chung, Ill-M; "Corrosion Inhibition Performance of Imidazolidine Derivatives for J55 Pipeline Steel in Acidic Oilfield Formation Water: Electrochemical, Surface and Theoretical Studies"; J. Taiwan Inst. Chem. Eng. 95, 341-356, 2019.

[15] Koopmans, T.; "Über Die Zuordnung Von Wellenfunktionen Und Eigenwerten $\mathrm{Zu}$ Den Einzelnen Elektronen Eines Atoms" Physica 1, 104-113, 1933.

[16] Kubba, R. M.; Al-Majidi, S. M. H.; Ahmed, A. H.; "Synthesis, Characterization and Quantum Chemical Studies of Inhibition Ability of Novel 5Nitro Isatin Derivatives on the Corrosion of Carbon Steel in Sea Water"; Iraqi J. Sci. 60(4), 688-705, 2019.

[17] Louadi, Y. E.; Abrigach, F.; Bouyanzer, A.; Touzani, R.; El-Assyry, A.,; Zarrouk, A.; Hammoutia, B.; "Theoretical and Experimental Studies on the Corrosion Inhibition Potentials of Two Tetrakis Pyrazole Derivatives for Mild Steel in 1.0m Hcl"; Portug. Electrochim. Acta 35(3), 159178, 2017.

[18] Parr, R. G.; Donnelly, R. A.; Levy, M.; Palke, W. E.; Empirical Evaluation of Chemical Hardness"; J. Chem. Phys. 68, 3801-3807, 1978.

[19] Speicher, C.; Dreizler, R.; "Density Functional Approach to Quantum Hadrodynamics: Theoretical Foundations and Construction of Extended Thomas- Fermi Models"; Ann. Phys. 213, 312-354, 1998. 


\section{Al-Nahrain Journal of Science \\ ANJS, Vol.23 (1), March, 2020, pp. 1-7}

[20] Kubba, R. M.; Alag, A. Sh.; "Experimental and Theoretical Evaluation of New Quinazolinone Derivative as Organic Corrosion Inhibitor for Carbon Steel in 1m Hcl Solution"; IJSR 6(6), 18321843, 2017.

[21] Ahmed, A. H.; Kubba, R. M.; Al-Majidi, S. M. H.; "Synthesis, Identification, Theoretical and Experimental Studies of Carbon Steel Corrosion Inhibition in Sea Water by Some New Diazine Derivatives Linked to 5-Nitro Isatin Moiety"; Iraq. J. Sci. 59(3b), 1347-1365, 2018.

[22] Kaskah, S. E.; "Surface Protection of Steel Cr4 by Using N-Acyl Sarcosine Derivatives in Salt Water"; Ph.D. Thesis, 2018.

[23] Hong, S.; Chen, W.; Luo, H. Q.; Li, N. B.; "Inhibition Effect of 4-Amino-Antipyrine on the Corrosion of Copper in 3 Wt.\% $\mathrm{NaCl}$ Solution"; Corrosion Science 57, 270-278, 2012.

[24] Acharya, S.; Upadhyay, S. N.; "The Inhibition of Corrosion of Mild Steel by Some Fluoroquinolones in Sodium Chloride Solution"; Trans. Indian Inst. Met. 57, 297-306, 2004.
[25] Hikmat, N. A.; Farhan, A. M; Majed, R. A.; "Thermodynamic And Kinetic Parameters for Corrosion Inhibition of $\mathrm{Al}-\mathrm{Cu}$ Alloy by Sodium Acetate at PH11"; Know Res. 1, 62-67, 2014.

[26] Obot, I. B.; Obi-Egbedi, N. O.; "Indeno-1-One [2,3B] Quinoxaline as an Effective Inhibitor for the Corrosion of Mild Steel in $0.5 \mathrm{~m} \mathrm{H}_{2} \mathrm{SO}_{4}$ Solution"; Mater. Chem. Phys. 122, 325-328, 2010.

[27] Ben Hmamou, D.; Aouad, M.; Salghi, R.; Zarrouk, A.; Assouag M.; Benali, O.; Messali, M.; Zarrok, H.; Hammouti, B.; "Inhibition of C38 Steel Corrosion in Hydrochloric Acid Solution by 4,5-Diphenyl-1hImidazole-2-Thiol:Gravimetric and Temperature Effects Treatments"; Int. J. Sci. Res. 4 (7), 34983504, 2012

[28] Fergachi, O.; Benhiba, F.; Rbaa, M.; Ouakki, M.; Galai, M.; Touir, R.; Lakhrissi, B.; Oudda, H.; EbnTouhami, M.; "Corrosion Inhibition of Ordinary Steel in $5.0 \mathrm{~m} \mathrm{HCl} \mathrm{Medium} \mathrm{by} \mathrm{Benzimidazole}$ Derivatives: Electrochemical, Uv-Visible Spectrometry and DFT Calculations"; J. Bio-TriboCorr., 5-21, 2019.

[29] Kubba, R. M.; Al-Majidi, S. M. H.; Ahmed, A. H.; "Synthesis, Characterization and Quantum Chemical Studies of Inhibition Ability of Novel 5Nitro Isatin Derivatives on the Corrosion of Carbon Steel in Sea Water"; Iraqi J. Sci. 60(4), 688-705, 2019. 